\title{
EFEKTIVITAS STRATEGI HEURISTIK DENGAN PENDEKATAN METAKOGNITIF DAN PENDEKATAN INVESTIGASI TERHADAP KEMAMPUAN PEMECAHAN MASALAH MATEMATIKA PADA MATERI POKOK BARISAN DAN DERET DITINJAU DARI KREATIVITAS SISWA KELAS XII MADRASAH ALIYAH DI PONTIANAK
}

\author{
Yudi Darma, Imam Sujadi
}

\begin{abstract}
The purposes of this research are to know of the effectiveness of heuristic learning strategy approach category, creativity, and its interaction to studentss mathematics problem solving ability on material series and sequence. This research is quasi experimental research with factorial design $2 \times 3$. The population is the studentss of class XII Madrasah Aliyah at Pontianak City the schools odd semester academic year of 2011/2012. The sampling was taken by using stratified cluster random. Sample of the research is 186 studentss. Data collecting is done through school document, problem solving essay test ability and creativity questionnaire. Instrument analysis that was done on essays problem solving ability is content validity, consist of analysis degree of differences, index of difficulty and reliability. Analysis on creativity questionnaire is content validity, internal consistency, and reliability. Data analysis technique used consisting of: Balance test, precondition analysis (Normality and Homogeneity). Hypothesis analysis test used was two way analysis of variance with unequal cell. Using $\alpha=0.05$ it can be concluded that: 1) Students who had been taught by using metacognitive learning approach result the better mathematics problem solving ability compared to students who had been taught by using investigation learning approach. 2) Students who have high creativity has better problem solving ability than students that have medium and low creativity, and students that have medium creativity have better problem solving ability than students who have low creativity. 3) Students who were taught by using metacognitive and also investigation learning approach, who have high creativity have better problem solving ability than students with medium and low creativity, and students who have medium creativity have better problem solving ability than students who have low creativity. 4) On high creativity level category, students who were taught by metacognitive learning approach have better mathematics problem solving ability than studentss who were taught by using investigation learning approach. Meanwhile on medium and low creativity, students who were taught by using metacognitive learning approach have the same mathematics problem solving ability with studentss who were taught by using investigation approach.
\end{abstract}

Key words: Heuristic strategy, Metacognitive, Investigation, Creativity and Problem Solving.

\section{PENDAHULUAN}

Pendidikan adalah usaha sadar dan terencana untuk mewujudkan suasana belajar dan proses pembelajaran agar peserta didik secara aktif mengembangkan potensi dirinya untuk memiliki kekuatan spiritual keagamaan, pengendalian diri, kepribadian, kecerdasan, 
akhlak mulia, serta keterampilan yang diperlukan dirinya dan masyarakat (UU SISDIKNAS No. 20 Tahun 2003).

Tajamnya persaingan global dalam berbagai aspek kehidupan manusia menuntut setiap individu anggota masyarakat mampu mengadaptasikan diri terhadap segala perubahan yang terjadi. Komponen utama yang sangat berperan dalam persaingan ini adalah kualitas sumber daya manusia. Seiring dengan berkembangnya pengetahuan dan tekhnologi, hal tersebut berbanding lurus dengan perubahan kehidupan yang begitu pesat. Artinya manusia dibutuhkan kecakapan diri, baik dari pola pikir, perilaku, serta keterampilan yang memadai untuk menyesuaikan perubahan tersebut. Tentunya kita dituntut untuk mampu meningkatkan kualitas diri dengan memiliki skill, kemampuan memecahkan masalah (problem solver) sehingga mampu mengatasi dan berkembang terhadap masalah atau tantangan-tantangan yang hadir dari pesatnya perubahan tersebut.

Salah satu strategi untuk meningkatkan kualitas sumber daya manusia tersebut adalah memposisikan sektor pendidikan sebagai alat utama dalam pembangunan. Matematika adalah salah satu ilmu dasar yang mempelajari peranan penting dalam berbagai aspek kehidupan, karena matematika merupakan ilmu universal yang mendasari perkembangan teknologi modern, mempunyai peran dalam berbagai disiplin dan mengembangkan daya pikir manusia (BSNP, 2006). Matematika merupakan alat yang efisien dan diperlukan oleh semua ilmu pengetahuan, dan tanpa bantuan matematika semuanya tidak akan mendapat kemajuan yang berarti (Sujono, 1988). Dengan demikian matematika memegang peranan bagi berlangsungnya perkembangan ilmu pengetahuan dan peradaban dunia.

Oleh karena itu, dalam rangka pelaksanaan pengajaran matematika diperlukan pembuatan rencana atau persiapan agar proses pembelajaran dapat lebih efektif, efesien, dan terarah. Efektif dalam proses dan pencapaian hasil belajar, efisien dalam penggunaan waktu, dan tenaga serta terarah pada pencapaiannya tujuan yang telah diterapkan.

Namun, kenyataan di lapangan belumlah sesuai dengan apa yang diharapkan. Masalah dalam pembelajaran matematika di Indonesia dapat dilihat pada hasil yang diraih oleh Indonesia pada ajang-ajang matematika Internasional. Berdasarkan prestasi yang diraih pada International Mathematics Olympiads (IMO), peserta didik Indonesia hanya menempati peringkat 42 dari 91 peserta pada tahun 2005, peringkat 52 dari 93 peserta tahun 2007, peringkat 36 dari 95 peserta pada tahun 2008, peringkat 43 dari 104 peserta 
pada tahun 2009, peringkat 30 dari 95 peserta pada tahun 2010, dan peringkat 29 dari 100 peserta pada tahun 2011 ( $\underline{\text { www.imo-official.org/results.aspx }}$ ). Berdasarkan data hasil dari Trends in International Mathematics and Science Study (TIMSS) tahun 2007 yang dikoordinir oleh The International for Evaluation of Education Achievement (IEA) menunjukkan bahwa kemampuan matematika peserta didik Indonesia (dengan rerata 397) menempati peringkat 36 dari 48 negara yang disurvei. Rerata nilai kemampuan matematika peserta didik Indonesia tersebut jauh di bawah rerata nilai kemampuan matematika peserta didik Malaysia (dengan rerata 474) dan Singapura (dengan rerata 593).

Rendahnya hasil belajar matematika dapat disebabkan oleh faktor kemampuan guru dalam menerapkan metode atau strategi pembelajaran yang kurang tepat, misalnya proses pembelajaran yang cenderung berpusat pada guru sementara siswa lebih cenderung pasif. Akibatnya siswa tidak mempunyai kesempatan untuk mengembangkan kemampuan berpikir matematikanya. Misalnya guru masih menggunakan metode mengajar yang bersifat mekanisitik, jarang memberikan masalah yang tidak rutin, dan lebih menekankan pada drill (Marpaung, 2003).

Menyadari pentingnya suatu strategi dan pendekatan pembelajaran untuk dapat mengembangkan kemampuan memecahkan masalah matematik siswa, maka mutlak diperlukan adanya pembelajaran matematika yang lebih banyak melibatkan siswa secara aktif dalam proses pembelajaran. Hal ini dapat terwujud melalui suatu bentuk pembelajaran alternatif yang dirancang sedemikian rupa sehingga mencerminkan keterlibatan siswa secara aktif dalam merespon pengetahuan. Pendidikan matematika sebagai bagian dari proses pendidikan secara umum, dihadapkan kepada tugas besar, yaitu mempersiapkan para siswa Indonesia untuk menjadi seorang pemecah masalah (problem solver) yang handal dalam menghadapi permasalahan yang bersifat matematis dalam kehidupan. Oleh karena itu, penulis menjadikan kemampuan pemecahan masalah dengan strategi heuristik sebagai salah satu fokus yang dikaji dalam penelitian ini.

Pentingnya pemilihan kemampuan pemecahan masalah matematika pada siswa dikemukakan oleh Branca (dalam Sumarmo, 1994) sebagai berikut: (1) kemampuan penyelesaian masalah merupakan tujuan umum pengajaran matematika, bahkan sebagai jantungnya matematika, (2) penyelesaian masalah meliputi metoda, prosedur dan strategi merupakan proses inti dan utama dalam kurikulum matematika, dan (3) penyelesaian matematika merupakan kemampuan dasar dalam belajar matematika. 
Kenyataan di lapangan, penekanan proses pembelajaran di sekolah terlalu banyak ditekankan pada aspek doing tetapi kurang menekankan pada aspek thinking. Apa yang diajarkan di ruang kelas lebih banyak berkaitan dengan masalah keterampilan manipulatif atau berkaitan dengan bagaimana mengerjakan sesuatu tetapi kurang berkaitan dengan mengapa demikian dan apa implikasinya.

Oleh sebab itu pembelajaran pemecahan masalah perlu dilakukan oleh guru dalam pembelajaran matematika, karena pemecahan masalah merupakan aktivitas yang penting berkaitan dengan kehidupan sehari-hari. Pemecahan masalah akan memberikan sejumlah pengalaman baru kepada siswa dalam memahami materi matematika secara khususnya maupun bidang studi lain secara globalnya.

Barisan dan deret merupakan salah satu materi yang terdapat dalam pelajaran matematika, dalam kehidupan sehari-hari, banyak persoalan yang dapat diselesaikan dengan menggunakan kaidah barisan maupun deret, misalnya perhitungan bunga bank, perhitungan kenaikan produksi, dan laba suatu usaha. Untuk menyelesaikan persoalan tersebut bisa menggunakan penyelesaian seperti penyelesaian pada materi barisan dan deret.

Pembelajaran matematika dengan strategi heuristik adalah pembelajaran matematika yang menitikberatkan pada aktivitas belajar, membantu dan membimbing peserta didik jika menemui kesulitan dan membantu mengembangkan kemampuan pemecahan masalahnya. Pembelajaran matematika dengan menggunakan strategi heuristik merupakan pembelajaran berpaham sistematis, yang menjadikan konflik kognitif sebagai titik awal proses belajar yang diatasi dengan regulasi pribadi (self regulation) tiap siswa untuk kemudian siswa tersebut membangun sendiri pengetahuannya melalui pengalaman dan interaksinya dengan lingkungan, artinya bagaimana guru membantu dan mengarahkan kepada siswa untuk berpikir dan mampu menyelesaikan masalah secara integratif.

Faktor yang masih sering diabaikan dalam berbagai penelitian pendidikan matematika adalah kreativitas belajar siswa, termasuk kreativitas berprestasi dalam belajar matematika. Seiring dengan perkembangan dunia komunikasi, stasiun televisi berlombalomba menarik perhatian masyarakat, dengan acara-acara menarik yang disiarkan pada saat-saat jam belajar siswa di rumah. Sebagian siswa tidak dapat menyikapi secara bijak terhadap fenomena ini, mereka menjadi kurang bersemangat dalam belajar, sebaliknya lebih semangat menonton televisi. Oleh karena itu perlu ada upaya meningkatkan 
kreativitas belajar siswa, khususnya kreativitas berprestasi dalam belajar matematika. Menyikapi hal tersebut pentingnya dilakukan sebagai upaya untuk mengungkap informasi secara komprehensip tentang gejala-gejala yang muncul dalam praktik pembelajaran terkait kreativitas berprestasi siswa dalam belajar matematika.

\section{METODE}

Penelitian ini dilaksanakan di MA yang ada di Kota Pontianak Provinsi Kalimantan Barat pada semester ganjil tahun pelajaran 2011/2012. Jenis penelitian ini adalah penelitian eksperimental semu. Populasi penelitian ini adalah seluruh peserta didik di 14 MA yang ada di Kota Pontianak. Pemilihan sampel menggunakan teknik stratified cluster random sampling sedemikian sehingga terpilih sampel penelitian sebagai berikut:

1) MA Negeri 2 Pontianak dengan kelas XII IPA-2 sebagai kelas eksperimen satu dan kelas XII IPA-1 sebagai kelas eksperimen dua.

2) MA Negeri 1 Pontianak dengan kelas XII IPA-1 sebagai kelas eksperimen satu dan kelas XII IPA-2 sebagai kelas eksperimen dua.

3) MA Syrif Hidayatullah dengan kelas XII IPA-1 sebagai kelas eksperimen satu dan kelas XII IPA-2 sebagai kelas eksperimen dua.

Metode pengumpulan data penelitian meliputi metode dokumentasi, tes, dan angket. Metode dokumentasi digunakan untuk memperoleh data kemampuan awal siswa. Metode tes digunakan untuk memperoleh data kemampuan pemecahan masalah siswa. Metode angket digunakan untuk memperoleh data kreativitas siswa.

Sebelum melakukan eksperimen, dilakukan uji keseimbangan terhadap kemampuan awal matematika menggunakan ui-t. Data kemampuan pemecahan masalah matematika dianalisis menggunakan analisis variansi dua jalan dengan sel tak sama. Sebelumnya, terhadap data kemampuan awal maupun kemampuan pemecahan masalah matematika dilakukan uji prasyarat meliputi uji normalitas populasi menggunakan metode Lillifors dan uji homogenitas variansi populasi menggunakan metode Bartlett. Selanjutnya apabila hasil analisis variansi menunjukkan $\mathrm{H}_{0}$ ditolak, dilakukan uji komparasi ganda menggunakan metode Scheffe'. 


\section{HASIL}

\section{Data Kemampuan Awal Matematika dan Uji Keseimbangan}

Berikut disajikan deskripsi data kemampuan awal matematika peserta didik kelas eksperimen satu dan kelas eksperimen dua.

Tabel Deskripsi Data Kemampuan Awal Matematika Peserta Didik

\begin{tabular}{|c|c|c|c|c|c|c|c|c|}
\hline \multirow{2}{*}{ Kelompok } & \multirow{2}{*}{$\mathbf{n}$} & \multicolumn{3}{|c|}{ Tendensi Sentral } & \multicolumn{4}{c|}{ Variabilitas Data } \\
\cline { 3 - 9 } & & $\overline{\mathbf{x}}$ & Mo & Me & Min & Maks & $\mathbf{R}$ & s \\
\hline Metakognitif & 88 & 67,01 & 60 & 67 & 33 & 100 & 67 & 12,8 \\
\hline Investigasi & 98 & 67,72 & 70 & 69 & 20 & 90 & 70 & 10,8 \\
\hline
\end{tabular}

Hasil uji prasyarat diperoleh simpulan bahwa sampel berasal dari populasi yang berdistribusi normal dan mempunyai variansi yang homogen. Hasil uji keseimbangan menggunakan uji- $t$ terhadap data kemampuan awal matematika peserta didik diperoleh simpulan bahwa populasi mempunyai kemampuan awal matematika yang seimbang.

\section{Data Penelitian dan Analisis Variansi Dua Jalan Dengan Sel Tak Sama}

Data yang digunakan dalam pengujian hipotesis adalah kemampuan pemecahan masalah matematika peserta didik pada materi pokok barisan dan deret.

Tabel Deskripsi Data Kemampuan Pemecahan Masalah Matematika Peserta Didik

\begin{tabular}{|c|c|c|c|c|c|c|c|c|c|}
\hline \multirow{2}{*}{$\begin{array}{l}\text { Pendekatan } \\
\text { Pembelajaran }\end{array}$} & \multirow{2}{*}{$\begin{array}{c}\text { Tingkat } \\
\text { Kreativitas }\end{array}$} & \multirow[b]{2}{*}{$\mathbf{n}$} & \multicolumn{3}{|c|}{ Tendensi Sentral } & \multicolumn{4}{|c|}{ Variabilitas Data } \\
\hline & & & $\overline{\bar{x}}$ & Mo & Me & Min & Maks & $\mathbf{R}$ & $\mathbf{S}$ \\
\hline \multirow{3}{*}{ Metakognitif } & Tinggi & 29 & 52,06 & 48 & 50 & 46 & 60 & 14 & 4,35 \\
\hline & Sedang & 29 & 43,93 & 44 & 44 & 34 & 50 & 16 & 3,79 \\
\hline & Rendah & 30 & 38,66 & 40 & 39 & 30 & 46 & 16 & 3,91 \\
\hline \multirow{3}{*}{ Investigasi } & Tinggi & 32 & 48,32 & 52 & 50 & 40 & 54 & 14 & 4,06 \\
\hline & Sedang & 34 & 42,29 & 38 & 42 & 38 & 48 & 10 & 3,68 \\
\hline & Rendah & 32 & 38,68 & 36 & 38 & 32 & 48 & 16 & 4,47 \\
\hline
\end{tabular}

Hasil uji prasyarat diperoleh simpulan bahwa sampel berasal dari populasi yang berdistribusi normal dan mempunyai variansi yang homogen. Berikut disajikan hasil analisis variansi dua jalan dengan sel tak sama.

Tabel Rangkuman Analisis Variansi Dua Jalan Dengan Sel Tak Sama

\begin{tabular}{|l|c|c|c|c|c|c|}
\hline \multicolumn{1}{|c|}{ Sumber } & Dk & JK & RK & Fobs $_{\text {Obs }}$ & $\mathbf{F}_{\boldsymbol{\alpha}}$ & $\begin{array}{c}\text { Keputusan } \\
\text { Uji }\end{array}$ \\
\hline Pendekatan Pembelajaran (A) & 1 & 149,036 & 149,036 & 9,06 & 3,92 & $\mathrm{H}_{0 \mathrm{~A}}$ ditolak \\
\hline Kreativitas Siswa (B) & 2 & 4165,198 & 2082,599 & 126,59 & 3,07 & $\mathrm{H}_{0 \mathrm{~B}}$ ditolak \\
\hline Interaksi (AB) & 2 & 110,902 & 55,451 & 3,37 & 3,07 & $\mathrm{H}_{0 \mathrm{AB}}$ ditolak \\
\hline Galat & 180 & 2961,20 & 16,45 & - & - & - \\
\hline \multicolumn{1}{|c|}{ Total } & $\mathbf{1 8 5}$ & $\mathbf{7 3 5 5 , 7 2}$ & & & & \\
\hline
\end{tabular}


Uji Komparasi Rerata Antar Baris (Pendekatan Pembelajaran)

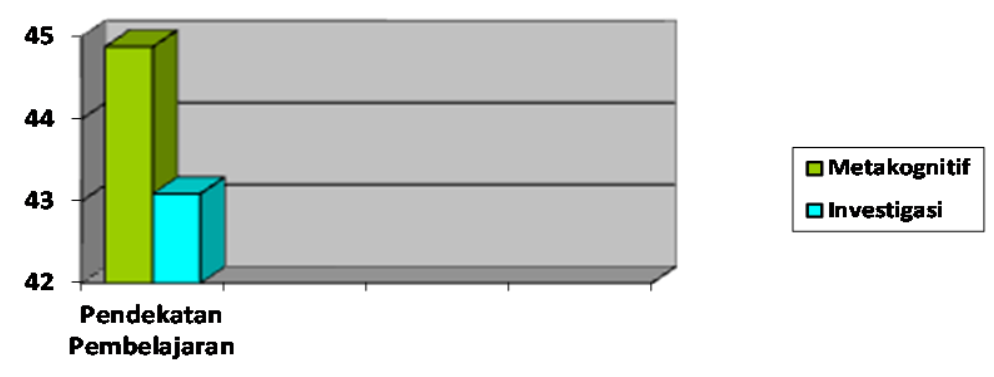

Gambar 1 Rerata Marginal Komparasi Ganda Antar Baris

\section{Uji Komparasi Rerata Antar Kolom (Kreativitas Siswa)}

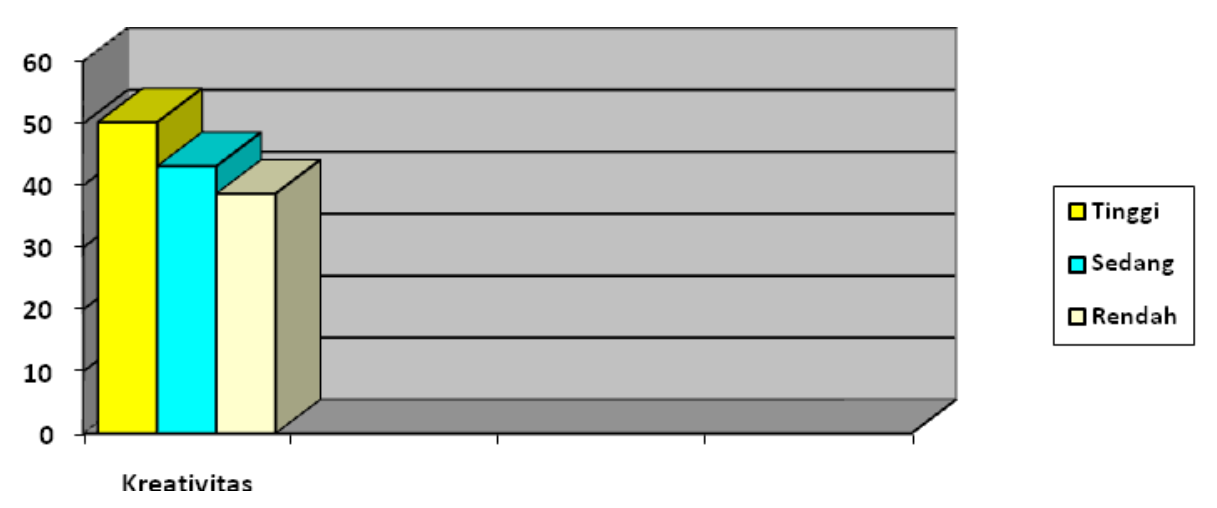

Gambar 2 Rerata Marginal Komparasi Ganda Antar Kolom 


\section{Uji Lanjut Antar Sel Pada Baris Yang Sama:}

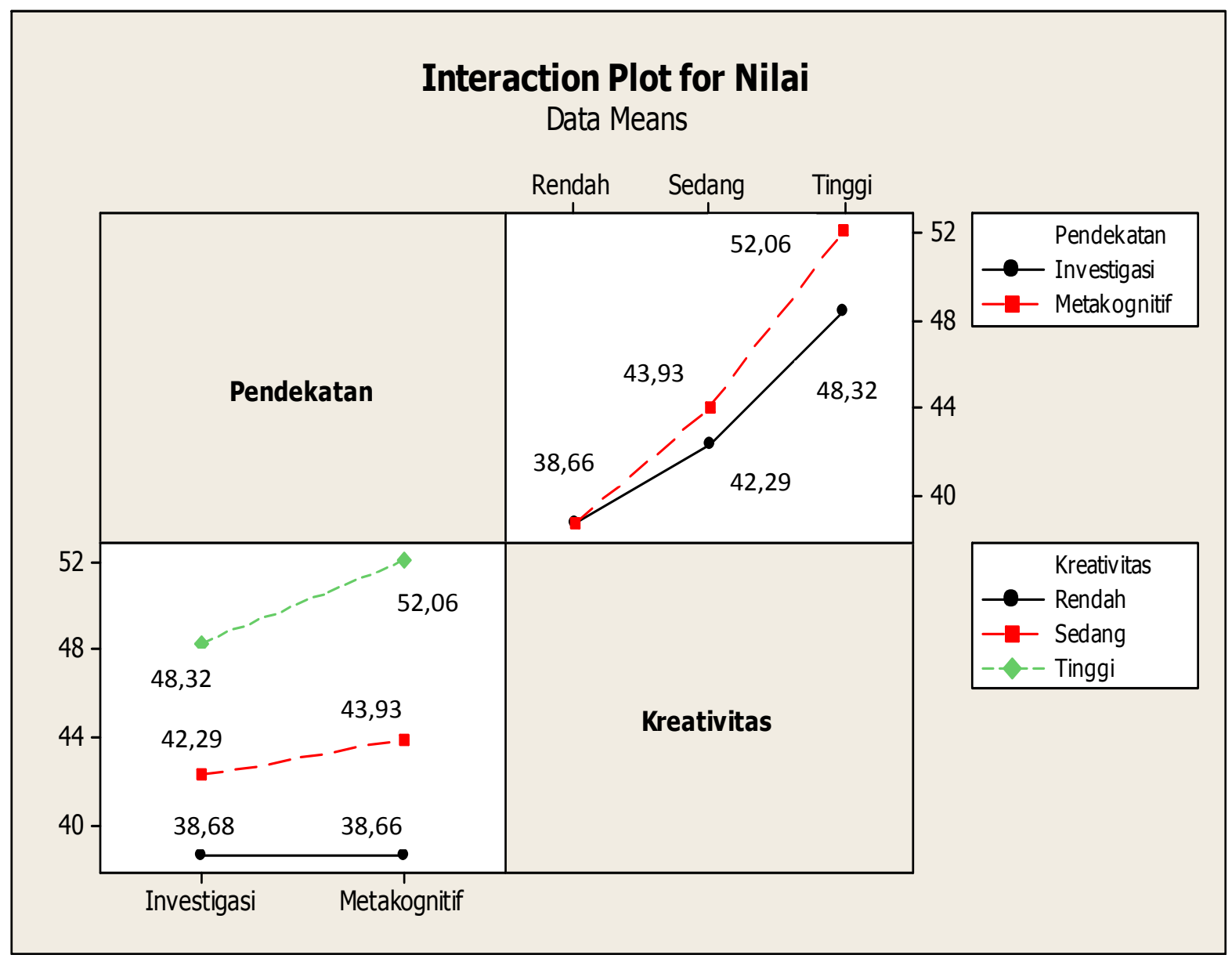

Gambar 3 Interaksi Antara Pendekatan Pembelajaran dan Kreativitas

\section{SIMPULAN}

Berdasarkan analisis data menggunakan analisis variansi dua jalan dengan sel tak sama, diperoleh simpulan bahwa: a) Pendekatan pembelajaran metakognitif pada strategi heuristik menghasilkan kemampuan pemecahan masalah yang lebih baik dari pada pendekatan pembelajaran Investigasi. b) Siswa yang memiliki kreativitas tinggi mempunyai kemampuan pemecahan masalah yang lebih baik daripada siswa yang memiliki kreativitas sedang maupun rendah, dan siswa yang memiliki kreativitas sedang mempunyai kemampuan pemecahan masalah yang lebih baik daripada siswa yang memiliki kreativitas rendah. c) Pada Siswa yang diberikan dengan pendekatan pembelajaran Metakognitif maupun Investigasi, siswa dengan kreativitas tinggi mempunyai kemampuan pemecahan masalah yang lebih baik daripada siswa dengan kreativitas sedang maupun rendah, dan siswa dengan kreativitas sedang mempunyai kemampuan pemecahan masalah yang lebih baik daripada siswa dengan kreativitas 
rendah.. d) Pada kategori tingkat kreativitas tinggi, siswa yang diberi pembelajaran dengan pendekatan Metakognitif memiliki kemampuan pemecahan masalah matematika yang lebih baik dibandingkan dengan siswa yang diberi pembelajaran dengan pendekatan Investigasi. Sedangkan pada kategori tingkat kreativitas sedang dan rendah, siswa yang diberi pembelajaran dengan pendekatan Metakognitif memiliki kemampuan pemecahan masalah matematika yang sama dengan siswa yang diberi pembelajaran dengan pendekatan Investigasi.

\section{SARAN}

Hendaknya termotivasi untuk menerapkan strategi dan pendekatan pembelajaran inovatif agar proses pembelajaran mampu mengoptimalkan kemampuan pemecahan masalah matematika siswa terhadap suatu konsep matematika. Salah satu strategi pembelajaran inovatif yang dapat diterapkan untuk mengoptimalkan kemampuan pemecahan masalah matematika adalah strategi heuristik dengan pendekatan metakognitif.

\section{DAFTAR PUSTAKA}

Bastow, B. Hughes, J. Kissane, B. \& Randall, R. 1986. Another 20 Mathematical Investigational Work. Perth: The Mathematical Association of Western Australia (MAWA).

BSNP. 2006. Standar Isi untuk Satuan Pendidikan Dasar dan Menengah. Jakarta.

Budiharjo. 2006. Penerapan Aspek Penilaian pada Penulisan Soal dan Pengolahan Nilai Rapor. Makalah pada Bintek Matematika. Semarang: tidak diterbitkan.

Budiyono. 2003. Metodologi Penelitian Pendidikan. Surakarta: UNS Press. 2009. Statistika Untuk Penelitian (Edisi Kedua). Surakarta : UNS Press.

Buzan, Tony \& Barry. 1993. Mind Map Book. New York : Printed in U.S.A.

Cardelle, M.E. 1995. Effect of Teaching Metacognitive Skills to Student with Low Mathematics Ability. In M.J. Dunkin \& N.L. Gage (Eds.), Teaching and Teacher Education : An International Journal of Research and Studies. 8, 109-111. Oxford : Pergamon Press.

Cifarelli, V.V. dan Cai, J. 2004. A Framework for Examining the Mathematical Exploration of Problem Solvers. [online] Tersedia dalam HTU.http://www.icmeorganisers.dk/tsg18/S61CifarelliCai.pdfUTH. diambil pada 06-01-2011 
Cockroft, W.H. 1986. Mathematics Counts. London: Her Majesty’s Stationery Office

Daniel Zingaro.2008, 18 Juli. "Group Investigation: Theory and Practice". Ontario Institute for Student in Education. Toronto. Ontario. http://www.danielzingaro.com/gi.pdf.

Dindyal, J. 2005. Emphasis on Problem Solving in Mathematics Textbooks from Two Different Reform Movements. Johor Baru Malaysia: The Mathematics Education into the 21st Century Project Universiti Teknologi Malaysia, Reform, Revolution and Paradigm Shifts in Mathematics Education, Johor Baru, Malaysia, Nov 25th - Dec 1st 2005

EUA. 2007. The Journal of Creativity in Higher Education. pp. 16-17. Belgia.

Greer, B. 1992. Multiplication and Division as Models of Situations. In D.A. Grouws (Eds.), Handbook of Educational Psychology (pp. 276-295). New York: Macmillan.

Garofalo, J. dan Lester F. 1985. Metacognition, Cognitive Monitoring and Mathematical Performance. Journal for Research in Mathematics Education.

Ivy Geok Chin Tan, Shlomo Sharan, Christine Kim Eng Lee. 2007. Group Investigation Effects on Achievement, Motivation, and Perceptions of Students in Singapore. International Journal of Educational Research. 100: 3, 142-154.

Imam Sujadi. 2011. Implementasi Matematika Terhadap Perkembangan Intelektual Peserta Didik. Sumbawa: Disampaikan Dalam Seminar Nasional Matematika di STKIP Hamzanwadi Selong.

Kirkley, J. 2003. Principles for Teaching Problem Solving. Indiana University : Plato Learning.

Marpaung, Y. 2003. Pembelajaran Matematika yang Menyenangkan. Makalah Seminar Nasional Komperda Himpunan Matematika Indonesia Wilayah Jawa Tengah dan DIY. Surakarta.

Muhibbin Syah. 2010. Psikologi Pendidikan dengan Pendekatan Baru., Bandung: Remaja Rosdakarya.

Mulyasa. 2006. Kurikulum Berbasis Kompetensi. Bandung : Remaja Rosdakarya.

NCTM. 2000. Principles and Standard for School Mathematics. Resto, Virginia: The National Council of Teachers of Mathematics, Inc.

Paul Suparno. 1997. Filsafat Kontruktivisme dalam Pendidikan. Yogyakarta: Kanisius. 
2001. Metodologi Pembelajaran Fisika Konstruktivistik dan Menyenangkan. Yogyakarta: Universitas Sanata Dharma.

Polya, George. 1973. How to Solve It - A New Aspect of Mathematical Method (Second edition). New Jersey : Princeton University Press

Ruseffendi, E. T. 1980. Pengantar kepada Membantu Guru Mengembangkan Kompetensinya dalam Pengajaran Matematika untuk Meningkatkan CBSA. Bandung: Tarsito.

Schoenfeld, Alan H. 1980. Heuristik in the Classroom, dalam Krulik, S. dan Reys, Robert E. (Eds). Problem Solving in School Mathematics. Virginia : NCTM.

Setiawan. 2006. Model Pembelajaran Matematika Dengan Pendekatan Investigasi. Makalah pada penulisan modulpaket pembinaan penataran. Yogyakarta: Depdiknas P3G Matematika.

Sugiyono. 2005. Statistik Untuk Penelitian. Bandun : Alfabeta

Sujono. 1988. Pengajaran Matematika untuk Sekolah Menengah. Jakarta: DEPDIKBUD.

TIMSS. 2004. Highlights From the Trends in International Mathematics and Science Study (TIMSS) 2003. [Online]. Tersedia: http://www.warwick.ac.uk/ETS/Publications/Guides/cal.htm. [13 Nopember 2010]

Utari Sumarmo. 1987. Kemampuan Pemahaman dan Penalaran Matematika Siswa SMA Dikaitkan dengan Kemampuan Penalaran Logik Siswa dan Beberapa Unsur Pembelajaran. Disertasi pada PPS UPI. Bandung: tidak diterbitkan. 